\title{
Ghrelin is Present in Teeth
}

\author{
Suleyman Aydin ${ }^{1, *}$, I brahim Hanefi Ozercan², Hikmet Geckil ${ }^{3}$, Ferda Dagli ${ }^{2}$, Suna Aydin $^{4,5}$, Sinem Kumru ${ }^{6}$, \\ Nermin Kilic ${ }^{1}$, İ brahim Sahin ${ }^{7}$ and Mehmet Resat Ozercan ${ }^{2}$ \\ ${ }^{1}$ Department of Biochemistry and Clinical Biochemistry, Firat University, Medical School (Firat Medical Center), 23119 Elazig, Turkey \\ ${ }^{2}$ Department of Pathology, Firat University, Medical School (Firat Medical Center), 23119 Elazig, Turkey \\ ${ }^{3}$ Department of Molecular Biology, Inonu University, Malatya 44280, Turkey \\ ${ }^{4}$ Department of Cardiovascular Surgery, and ${ }^{5}$ Anatomy, Firat University, Medical School (Firat Medical Center), 23119 Elazig, Turkey \\ ${ }^{6}$ Doctors Business Center, Tooth Clinic, Elazig, Turkey \\ ${ }^{7}$ Biochemistry section-Biology, Firat University, 23119 Elazig, Turkey
}

Received 10 November 2006, Accepted 21 December 2006

\begin{abstract}
Ghrelin belongs to the family of a gut-brain hormone that promotes food intake and controls energy balance. Recently, it has also been shown to regulate bone formation directly. Dental tissue shares several functional, developmental and anatomical similarities with bone, and in the present study we have investigated the presence of ghrelin in 44 human teeth using immunocytochemistry and radioimmunoassay. Both methods showed that the hormone is present in canines and molars, mainly in the odontoblasts but also in the pulp. Ghrelin could potentially play interesting physiological roles in teeth.
\end{abstract}

Keywords: Ghrelin, Odontogenic cell, Peptide hormones, Tooth

\section{Introduction}

Ghrelin, a $3.3 \mathrm{kDa}$ peptide hormone, an endogenous ligand for the growth hormone (GH) secretagogue receptor (GHSR), was originally recognized in extracts of rat and human stomach, where it is located in the endocrine X/A-like cells of the gastric mucosa, and they named it "ghrelin" based on its role as a "Growth Hormone Releasing Peptide", with allusion to the Proto-Indo-European root ghre meaning "grow (Kojima et al., 1999). Ghrelin is a 28-amino acid peptide in which serine-3 is an $n$-octanoylated; this modification is essential for the binding of acylated ghrelin to its receptor and for functions such as

PS: This work was presented as a poster at the Second Turkey Ecopathology Congress, July 2, Elazig/Turkey

*To whom correspondence should be addressed.

Tel: 90-533-493-4643; Fax: 90-424 2388660

E-mail: saydin1@hotmail.com appetite stimulation. In this respect, ghrelin is the first known example of a peptide hormone modified by a fatty acid. Also, it is known that the activity of desacylated ghrelin does not require binding to the growth hormone secretory receptor-1a (GHSR-1a) (Kojima and Kangawa. 2005; Aydin et al., 2006a).

Ghrelin is produced predominantly by stomach tissue but is also expressed in many other tissues including placenta, pancreas, hematopoietic cells, liver, lung (Kojima and Kangawa, 2005; Aydin et al., 2006a) and breast tissue (Kierson et al., 2006). Ghrelin mRNA has also been found in other tissues (Gnanapavan et al., 2002), and the hormone has been reported in many biological fluids such as blood (Kojima and Kangawa, 2005; Aydin et al., 2006a), cerebrospinal fluid (Tritos et al., 2003), milk (Aydin et al., 2006b; Kierson et al., 2006) and saliva (Aydin et al., 2005a; Groschl et al., 2005; Aydin et al., 2006c; Groschl et al., 2006). More recent work in our laboratory showed that ghrelin is also present in plants (Aydin et al., 2006d).

Ghrelin plays an important role in body weight homeostasis through effects on food intake and energy expenditure in many tissues (Kojima and Kangawa. 2005; Aydin et al., 2006a). It promotes appetite and influences hematopoiesis, reproduction, angiogenesis, immune processes, bone formation (Fukushima et al., 2005), and tissue growth regulation through interaction with one or more growth factor receptors (Kojima and Kangawa. 2005). The absence of ghrelin is a symptom of gastric cancer (Aydin et al., 2005b). Thus, defective ghrelin signaling from the stomach or other ghrelinproducing organs could contribute to abnormalities in growth, energy balance, and associated gastrointestinal and neuroendocrine functions (Inui A et al., 2004; Kojima and Kangawa. 2005).

Dental tissue contains various peptides such as neuropeptides, calcitonin gene-related peptide (CGRP), substance P (SP), vasoactive intestinal polypeptide (VIP), neuropeptideY (NPY), galanin (GAL), enkephalin (ENK) and somatostatin (SOM) 
(Rodd and Boissonade, 2003). The maintenance of hard tissue in tooth and bone depends upon the stimulation of morphologically and functionally related cells, namely odontoblasts and osteoblasts (Rani and MacDougall, 2000). Dental tissue shares several functional, developmental and anatomical similarities with bone (Rani and MacDougall, 2000). Delhanty and his co-workers showed that both human bone biopsies and osteoblasts expressed ghrelin mRNA, and osteoblasts were found to release ghrelin (Delhanty et al., 2006). Some previous works did observe an association between ghrelin and bone (Kim et al., 2005; Fukushima et al., 2005; Misra et al., 2005), and also had a relationship with bone turnover (Weiss et al., 2006).

To our knowledge, expression and immunohistochemical localization of ghrelin have not yet been explored in tooth tissue. Therefore, the aim of our study was to investigate whether human tooth tissue expresses this multifunctional hormone and to identify any differences in ghrelin immunohistochemistry between canines and molars.

\section{Methods}

Experimental material. Teeth (18 dentes canines and 26 dentes molares) were removed for various reasons from patients of unknown age, sex and race in the Elazig Tooth Hospital (Elazig, Turkey). They were cleaned with a curette to remove all traces of hard and soft tissue, washed in running water for $4 \mathrm{~h}$, then placed in a container of formalin $(10 \%)$ : nitric acid $(15.4 \mathrm{M})$ : distilled water $(10: 5: 85 \mathrm{v} / \mathrm{v})$ until decalcification was complete (one week). After decalcification, the teeth were washed in runnïng water for 8 hours to remove all the remaining acid, then paraffin blocks were prepared for Immunohistochemistry (IHC). The study was approved by the Ethics Committee of Firat University, School of Medicine.

Immunohistochemistry (IHC). Immunohistochemical staining was carried out using the streptavidin-avidin-biotin-peroxidase complex (ABC) method (Hsu et al., 1981) with minor modifications (Aydin et al., 2005b). First, microtome (Histoslide 2000, Reichert-Jung, Heidelberg) sliced $4-\mu \mathrm{m}$ thick sections were mounted on silanized slides, de-waxed in xylene, dehydrated with alcohol, immersed in $3 \%$ hydrogen peroxide in methanol for 10 min to block endogenous peroxidase activity and immunostained using the $\mathrm{ABC}$ procedure. $\mathrm{ABC}$ was prepared according to manufacturer's protocol ( $\mathrm{Lab}$ Vision Corporation). The tooth tissue sections were then placed in citrate buffer $(\mathrm{pH} 6.0)$, incubated in a $650 \mathrm{~W}$ microwave oven for $5 \mathrm{~min}$, and washed with $0.01 \mathrm{M}$ phosphate buffer, $\mathrm{pH} 7.4$ (PBS). Blocking reagent was applied at this point in the assay for $10 \mathrm{~min}$ to eliminate nonspecific antibody binding. Next, the sections were incubated at $38^{\circ} \mathrm{C}$ for $30 \mathrm{~min}$ in rabbit anti-ghrelin (human), Phoenix, diluted $1: 500$ (Catherine et al., 2004) in PBS (Phoenix Inc) suggested dilution of 1 in 70, was found to produce unacceptable levels background staining), then washed in PBS, incubated with biotinylated goat anti-polyvalent (Lab Vision Corporation) at $38^{\circ} \mathrm{C}$ for $2 \times 15 \mathrm{~min}$, and washed again in PBS. Streptavidin-biotinperoxidase complex was applied to each tissue section for $10 \mathrm{~min}$ and then the tissues were washed twice in PBS for $5 \mathrm{~min}$. Amino

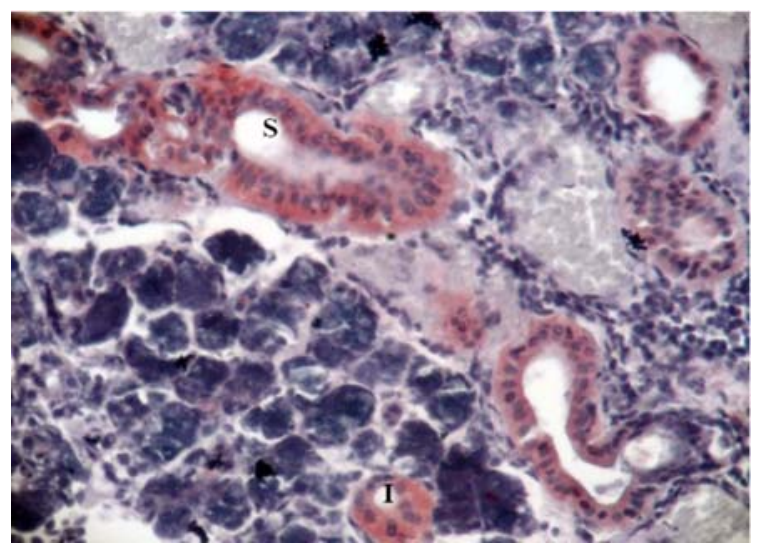

Fig. 1. Ghrelin IHC of normal salivary gland as positive control. ghrelin in the intercalated (I) and striated ducts (S). Magnification, $\times 200$.

ethyl carbazole (AEC) was applied as a chromogen for $10 \mathrm{~min}$. Finally, the sections were counterstained with Mayer's hematoxylin for 1-2 min, washed with distilled water, dried and mounted. Negative controls were prepared from similarly-treated adjacent sections omitting the primary antibody, and no positive immunostaining was detected. Positive controls were performed using normal human salivary gland tissue (Fig. 1). Slides were examined under a light microscope.

Sample preparation and ghrelin assay. The homogenate was prepared by carefully removing $15 \mathrm{mg}$ of tooth tissue and crushing with an iron mold. The crushed samples were then homogenized in PBS $(5 \%, \mathrm{w} / \mathrm{v})$ using a stainless-steel mortar and the homogenates were centrifuged at $9800 \mathrm{rpm}$ for $20 \mathrm{~min}$ at $4^{\circ} \mathrm{C}$. The supernatant was separated, supplemented with $20 \mu \mathrm{g} / \mathrm{ml}$ aprotinin and $1 / 10$ volume $1 \mathrm{~N} \mathrm{HCl}$, and stored frozen (Aydin et al., 2006b). Tooth tissue ghrelin was measured as previously described (Aydin et al., 2005b) using a commercially-available radioimmunoassay (Phoenix Europe, Karlsruhe, Germany) that is designed to test any biological fluid with sufficient levels of the peptide to be determined. The tissue ghrelin assay was validated according to procedures previously published by Aydin (2006d). The validation results for the tissue ghrelin assay were as follows. The lower detection limit was $1.7 \mathrm{fmol} / \mathrm{ml}$. The inter-assay coffecient of variation (CV) was $10.2 \%$ and the inter-assay CV was $7.9 \%$. The assay was also shown to be linear after dilution. The mean apparent recovery was $92.4 \%$ (95\% confidence interval, 91.8\%-109\%). The use of tooth extract by itself did not interfere with the assay.

Kits and reagents. The ghrelin radioimmunoassay kit (Cat: RK 031-30), rabbit anti-ghrelin (human) serum and the antibody for immunohistochemistry (Cat: H-031-30) were obtained from Phoenix Europe, Karlsruhe, Germany. Pepsin solution (Cat: TA-125-PE), biotinylated goat anti-polyvalent (Cat: TP-125 BN), large volume streptavidin peroxidase (TS-125-HR), chromogen substrate (TA060-HAS), AEC chromogen (TA-004-HAC), amino ethyl carbazole (Cat: TA-125-HAS), and phosphate buffer (Cat no: TA-125-PB) were from Lab Vision Corporation Fremont, CA, USA. Formaldehyde (Cat: 3010) was purchased from GBL, Gul Biology laboratory, 

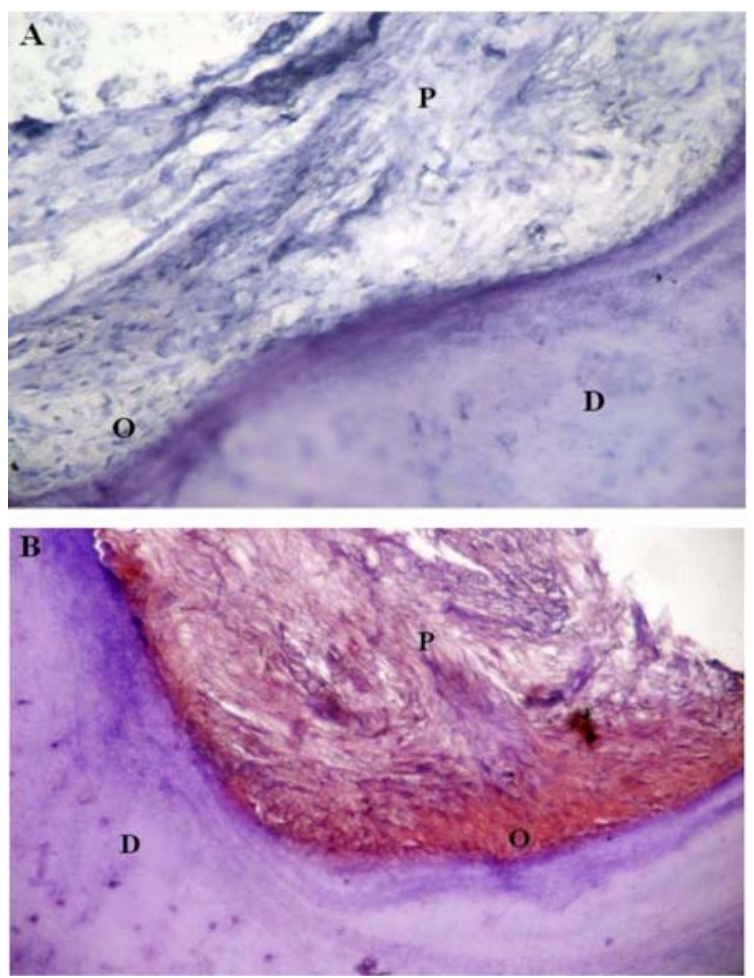

Fig. 2. Immunohistochemical reactivity of ghrelin in dentes molares (the longitudinal section). (A) Negative control; (B) immunoreactive odontoblasts $(\mathrm{O})$ are heavily and pulp cells $(\mathrm{P})$ moderately labeled with anti-human ghrelin antibody; $\mathrm{D}=$ dentine. Magnification $\times 200$.

Dudulu, Istanbul, Turkey. Nitric acid $\left(\mathrm{HNO}_{3}\right.$; Cat: 07006$)$ was purchased from Riedel-deHaën, Seelze, Germany.

\section{Results}

Positive controls were performed using normal human salivary gland tissue (Fig. 1). The salivary immunohistochemistry results also confirmed our previously published data (Aydin et al., 2005b; Aydin et al., 2006c). The immunohistochemical localization of ghrelin in tooth tissues is shown in Figs. 2 and 3. It is apparent that ghrelin is mainly located in odontoblasts (OC), where a heavy labeling with anti-human ghrelin antibody is observed. Also, a moderate immunoreactivity to ghrelin was observed in the pulp (P). The presence of ghrelin was confirmed through radioimmunoassay and highly specific immmunohistochemical analysis using a human anti-ghrelin antibody. The ghrelin concentration in tooth tissue extracts was determined using a standard curve generated with commercially-available human ghrelin, a solid-phase synthesized peptide. In view of interference from other cellular compounds, a method for hormone analysis should not only be specific but also highly sensitive. Our preliminary studies showed that the lowest level of ghrelin detectable by this method was about
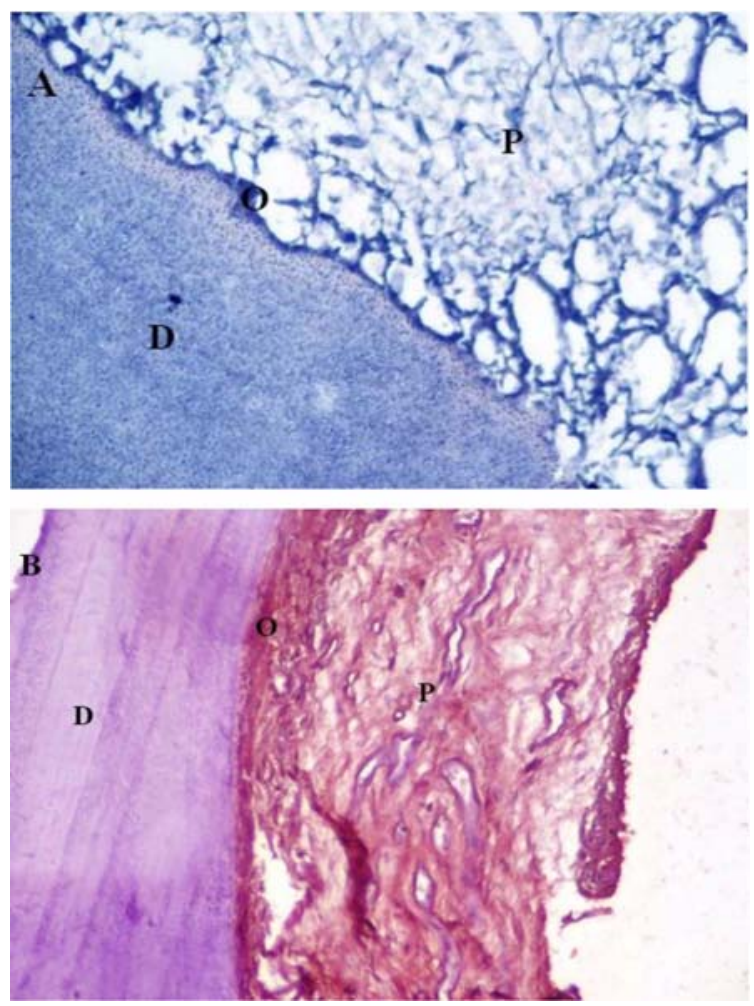

Fig. 3. Immunohistochemical reactivity of ghrelin in dentes canines (longitudinal section). (A) Negative control; (B) immunoreactive odontoblasts (O) are heavily and pulp cells (P) moderately labeled through binding of anti-human ghrelin antibody; $\mathrm{D}=$ dentine. Magnification $\times 200$.

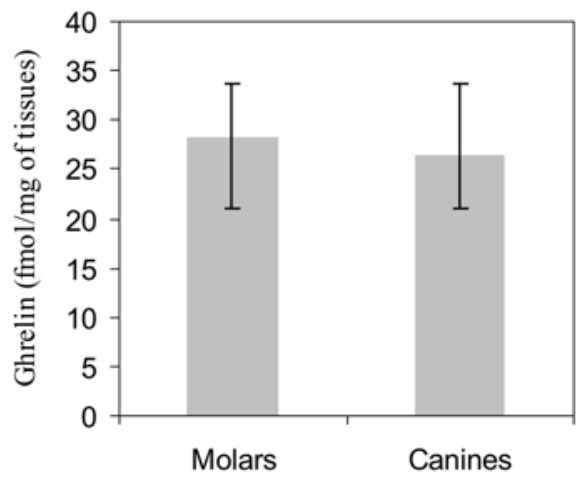

Fig. 4. Ghrelin levels per mg of tissue in human teeth. Dentes molares tissue levels are averages from 26 teeth. Dentes canines tissue levels are averages from 18 teeth.

$1.65 \mathrm{fmol} / \mathrm{mg}$ human tissue, making the assay highly sensitive. RIA analysis in canines and molars showed $26.4( \pm 5.2)$ and 28.1. ( \pm 5.9$)$ fmol ghrelin per milligram of tissue, respectively. These data are presented in Fig. 4. The ghrelin level in the dentes molares is an average from 26 teeth while that from the dentes canines is an average from 18 teeth. 


\section{Discussion}

In this study we attempted to determine whether teeth contained this multifunctional peptide hormone. Ghrelin was found to be mainly located in odontogenic cells (OC) and there was weaker staining with anti-human ghrelin antibody in the pulp. Our results are consistent with the production of other tooth proteins, which has been demonstrated in human odontoblasts. For example, galanin has been found in the tooth pulps of man, dog, cat and rat by Wakisaka et al., 1996. Also, Pertl and his co-workers used immunocytochemistry and radioimmunoassay to demonstrate the presence of secretoneurin in human tooth pulp (Pertl et al., 1998).

Since immunohistochemistry showed stronger ghrelin staining in the odontoblasts than in the pulp, it is clear that odontoblasts express ghrelin; but whether pulp produces it is questionable, even though many peptides (e.g. vasoactive intestinal polypeptide, neuropeptide) have been found in the tooth pulp of various species including man (Rani and MacDougall, 2000). Here, we tentatively assumed that the pulp ghrelin probably originates from either the odontoblasts or tooth blood vessels, hence the weaker staining. Supporting later notion, it was found that ghrelin cells in the intestine become increasingly "open" both intestinal lumen and blood vessels (Sakata et al., 2002).

Odontoblasts are highly specialized neural crest-derived cells aligned in a single layer at the edge of the dental pulp. The adult pulp contains macrophages and nerves and capillary cells (Rodd and Boissonade, 2002). The odontoblasts secrete several collagenous and non-collagenous proteins to form a unique extracellular matrix. Type I collagen, proteoglycans and Dentin sialophosphoprotein are among the few molecules that are synthesized and secreted by the odontoblasts (Sreenath et al., 2003). Given this information, it is possible that ghrelin in the odontoblast cell layer may play a role in dentinogenesis, and the mineralization process. Because, phosphoproteins, sialoproteins, proteoglycans and growth factors (if the same hold true for ghrelin) interact with each other to form predentin, which subsequently mineralizes to form dentin(Sreenath et al., 2003). Also, ghrelin originating perhaps from teeth might be involved in stimulating the feeding centers similarly as for ghrelin released the gastric mucosa and other sources (salivary gland, adrenal cortex, kidney and so).

Ghrelin activity in teeth was also verified through a ghrelinspecific radioimmunoassay. Our preliminary studies with commercial human ghrelin showed that the RIA kit, mainly used to determine human plasma ghrelin levels, could also be used to determine the level of this hormone in human tissue extracts. We found a ghrelin level of $26.4 \mathrm{fmol} / \mathrm{mg}$ tissue in the dentes canines tissue while the dentes molares contained $28.2 \mathrm{fmol} / \mathrm{mg}$ of tissue. Normal salivary gland contained 36.8 $\mathrm{fmol} / \mathrm{mg}$ of tissue. Those levels of ghrelin were low as compared to that presented in the gastric mucosa (Kojima and Kangawa, 2005), but higher than many tissues, include the lungs, gonads, adrenal cortex and more in which ghrelin were often detectable only by RT-PCR (Gnanapavan et al., 2002). The limitation of this study is related to the ghrelin receptor; further research is needed to establish firmly whether the ghrelin receptor is present in teeth.

One important question arises from these tooth ghrelin level results and previous reports (Kojima and Kangawa, 2005; reviewed, Aydin et al., 2006a): does the stomach really produce $65 \%$ of the body's total ghrelin? This figure seems unexpectedly high, given that ghrelin is expressed in almost all human tissues including tooth and breast. After gastrectomy, other organs might increase their capacity to produce ghrelin and release it into the blood stream; thus, the stomach capacity would be expected to be less than $65 \%$ of the body's total ghrelin. Studies are needed to establish reliable figures for ghrelin levels in all tissues.

In conlusion, the physiological significance of ghrelin in teeth remains to be elucidated; further studies are needed to determine its potential interaction with other regulatory hormones in the body and with other peptides in teeth. Ghrelin is a growth-related hormone expressed in almost all tissues of human and other mammals (Kojima and Kangawa, 2005; Aydin et al., 2006a), and along with growth hormone it promotes bone formation through ligation with growth factor (GF) receptors on osteoblast surfaces and stimulation of insulin-like GF-1 (Bryant et al., 2005). This localization of ghrelin might contribute to nutrient uptake by teeth, tooth healing as well as regeneration (Balasubramaniam et al., 2006; Konturek et al., 2006), and dentinogenesis.

Acknowledgments The authors were grateful to Elazig Tooth Hospital for providing teeth, and their special thanks go to Bilal Polat for collecting teeth.

\section{References}

Aydin, S. (2007) A comparison of ghrelin, glucose, alpha-amylase and protein levels in saliva from diabetics. J. Biochem. Mol. Biol. 40, 29-35.

Aydin, S., Aydin, S., Ozkan, Y. and Kumru S. (2006b) Ghrelin is present in human colostrum, transitional and mature milk. Peptides 27, 878-882.

Aydin, S., Halifeoglu, I., Ozercan, I. H., Erman, F., Kilic, N., Aydin, S., Ilhan, N., Ilhan, N., Ozkan, Y., Akpolat, N., Sert, L. and Caylak, E. (2005a) A comparison of leptin and ghrelin levels in plasma and saliva of young healthy subjects. Peptides 26, 647-652.

Aydin, S., Geckil, H., Zengin, F., Ozercan, IH., Karatas, F., Aydin, S., Turgut-Balik, D., Ozkan, Y., Dagli, F. and Celik, V. (2006d) Ghrelin in plants: What is the function of an appetite hormone in plants? Peptides 27, 1597-1602.

Aydin, S., Ozkan, Y., Caylak, E. and Aydin, S. (2006a) Ghrelin and its biochemical functions. Turkiye Klinikleri J. Med. Sci. 26, 272-283.

Aydin, S., Ozercan, IH., Dagli, F., Aydin, S., Dogru, O., Celebi, S., Akin, O. and Guzel, S. P. (2005b) Ghrelin immuno- 
histochemistry of gastric adenocarcinoma and mucoepidermoid carcinoma of salivary gland. Biotech. Histochem. 80, 163-168.

Aydin, S., Ozercan, I. H., Aydin, S., Ozkan, Y., Dagli, F., Oguzoncul, F. and Geckil, H. (2006c) Biological rhythm of saliva ghrelin in human. Biol. Rhythm Res. 37, 169-177.

Balasubramaniam, A., Wood, S., Joshi, R., Su, C., Friend, L. A., Sheriff, S. and James, J. H. (2006) Ghrelin stimulates food intake and growth hormone release in rats with thermal injury: Synthesis of ghrelin. Peptides 27, 1624-1631.

Bryant, D. M., Wylie, F. G. and Stow, J. L. (2005) Regulation of endocytosis, nuclear translocation and signaling of fibroblast growth factor receptor 1 by E-cadherin. Mol. Biol. Cell. 16, 1423.

Catherine, L., Prado, Aimee E. Pugh-Bernard, Lynda Elghazi, Beatriz Sosa-Pineda and Lori Sussel (2004) Ghrelin cells replace insulin-producing $\beta$ cells in two mouse models of pancreas development. Proc. Natl. Acad. Sci. USA 101, 29242929.

Delhanty, P. J., van der Eerden, B. C., van der Velde, M., Gauna, C., Pols, H. A., Jahr, H., Chiba, H., van der Lely, A. J. and van Leeuwen, J. P. (2006) Ghrelin and unacylated ghrelin stimulate human osteoblast growth via mitogen-activated protein kinase (MAPK)/phosphoinositide 3-kinase (PI3K) pathways in the absence of GHS-R1a. J. Endocrinol. 188, 3747.

Fukushima, N., Hanada, R., Teranishi, H., Fukue, Y., Tachibana, T., Ishikawa, H., Takeda, S., Takeuchi, Y., Fukumoto, S., Kangawa, K., Nagata, K. and Kojima, M. (2005) Ghrelin directly regulates bone formation. J. Bone Miner. Res. 20, 790798.

Gnanapavan, S., Kola, B., Bustin, S. A., Morris, D. G., McGee, P., Fairclough, P., Bhattacharya, S., Carpenter, R., Grossman, A. B. and Korbonits, M. (2002) The tissue distribution of the mRNA of Ghrelin and subtypes of its receptor, GHS-R, in humans. Clin. Endocrinol. Metab. 87, 2988-2991.

Groschl, M., Topf, H. G., Bohlender, J., Zenk, J., Klussmann, S., Dotsch, J., Rascher, W. and Rauh, M. (2005) Identification of ghrelin in human saliva: production by the salivary glands and potential role in proliferation of oral keratinocytes. Clin. Chem. 51, 997-1006.

Groschl, M., Topf, H. G., Rauh, M., Kurzai, M., Rascher, W. and Kohler, H. (2006) Postprandial response of salivary ghrelin and leptin to carbohydrate uptake. Gut. 55, 433-434.

Inui, A., Asakawa, A., Bowers, C. Y., Mantovani, G., Laviano, A., Meguid, M. M. and Fujimiya, M. (2004) Ghrelin, appetite, and gastric motility: the emerging role of the stomach as an endocrine organ. FASEB J. 18, 439-456.

Hsu, S. M., Raine, L. and Fanger, H. (1981) Use of avidin-biotinperoxidase complex $(\mathrm{ABC})$ in immunoperoxidase technique. $J$. Histochem. Cytochem. 29, 577-580.

Kierson, J. A., Dimatteo, D. M., Locke, R. G., Mackley, A. B. and Spear, M. L. (2006). Ghrelin and cholecystokinin in term and preterm human breast milk. Acta Paediatr. 95, 991-995.

Kim, S. W., Her, S. J., Park, S. J., Kim, D., Park, K. S., Lee, H. K., Han, B. H., Kim, M. S., Shin, C. S. and Kim, S. Y. (2005) Ghrelin stimulates proliferation and differentiation and inhibits apoptosis in osteoblastic MC3T3-E1 cells. Bone 37, 359-369.

Kojima, M. and Kangawa, K. (2005) Ghrelin structure and function. Physiol. Rev. 85, 495-522.

Kojima, M., Hosoda, H., Date, Y., Nakazato, M., Matsuo, H. and Kangawa, K. (1999) Ghrelin is a growth-hormone-releasing acylated peptide from stomach. Nature 402, 656-660.

Konturek, P. C., Brzozowski, T., Walter, B., Burnat, G., Hess, T., Hahn, E. G. and Konturek, S. J. (2006) Ghrelin-induced gastroprotection against ischemia-reperfusion injury involves an activation of sensory afferent nerves and hyperemia mediated by nitric oxide. Eur. J. Pharmacol. 536, 171-181.

Misra, M., Miller, K. K., Stewart, V., Hunter, E., Kuo, K., Herzog, D. B. and Klibanski, A. (2005) Ghrelin and bone metabolism in adolescent girls with anorexia nervosa and healthy adolescents. J. Clin. Endocrinol. Metab. 90, 5082-5087.

Pertl, C., Kaufmann, W., Amann, R., Heinemann, A., Ebeleseder, K., Polansky, R., Saria, A., Kim, S. (1998) Secretoneurin, a novel neuropeptide, in the human dental pulp. Arch. Oral. Biol. 43, 361-365.

Rani, C. S. and MacDougall, M. (2000) Dental cells express factors that regulate bone resorption. Mol. Cell. Biol. Res. Commun. 3, 145-152.

Rodd, H. D. and Boissonade, F. M. (2002) Comparative immunohistochemical analysis of the eptidergic innervation of human primary and permanent tooth pulp. Arch. Oral. Biol. 47, 375-385.

Sakata, I., Nakamura, K., Yamazaki, M., Matsubara, M., Hayashi, Y., Kangawa, K. and Sakai, T. (2002) Ghrelin-producing cells exist as two types of cells, closed- and opened-type cells, in the rat gastrointestinal tract. Peptides 23, 531-536.

Sreenath, T., Thyagarajan, T., Hall, B., Longenecker, G., D’Souza, R., Hong, S., Wright, T., MacDougall, M., Sauk, J. and Kulkarni, A. B. (2003) Dentin sialophosphoprotein knockout mouse teeth display widened predentin zone and develop defective dentin mineralization similar to human dentinogenesis imperfecta type III. J. Biol. Chem. 278, 24874-24880.

Tritos, N. A., Kokkinos, A., Lampadariou, E., Alexiou, E., Katsilambros, N. and Maratos-Flier, E. (2003) Cerebrospinal fluid ghrelin is negatively associated with body mass index. $J$. Clin. Endocrinol. Metab. 88, 2943-2946.

Wakisaka, S., Itotagawa, T., Youn, SH., Kato, J. and Kurisu, K. (1996) Distribution and possible origin of galanin-like immunoreactive nerve fibers in the mammalian dental pulp. Regul. Pept. 62, 137-143.

Weiss, L. A., Langenberg, C. and Barrett-Connor E. (2006) Ghrelin and bone: is there an association in older adults?: the Rancho Bernardo study. J. Bone Miner. Res. 21, 752-757. 